\title{
An Economic Analysis of Production and Marketing in Rapeseed-Mustard Crop in Meerut District of Western Uttar Pradesh, India
}

\author{
Prince Kumar ${ }^{*}$ K.K. Singh, Rajeev Singh, Swatantra Pratap Singh and \\ Yamuna Prasad Singh
}

Department of Agricultural Economics, Narendra Deva University of Agriculture and Technology, Narendra Nagar, Kumarganj, Faizabad (U.P.) 224 229, India

*Corresponding author

\section{A B S T R A C T}

An attempt has been made in this study to examine the economic analysis of production and marketing of rapeseed-mustard in Meerut district of Western Uttar Pradesh State, India. The study was conducted in Sardhana and Sharurpur Khurd blocks in Meerut district of Uttar Pradesh State, India. Hundred farmers were selected randomly from ten villages from these blocks to collect the required information on the cost of cultivation, marketing and other aspects for the present study. The primary data was collected from the rapeseed-

\section{Keywords}

Rapeseed-mustard, Cost and returns, Marketing.

Article Info

Accepted:

14 July 2017

Available Online:

10 September 2017 mustard producers through personal interview method with the help of well-prepared schedule and questionnaire for the production and post-harvest year for Rabi rapeseedmustard 2012-13. The average cost of cultivation and input-output ratio of rapeseedmustard was worked out as Rs. 50310.84 /ha. And 1: 1.22. The average Cost A1, Cost B1, Cost B2, Cost C1, and Cost C2 were observed as Rs.30294.63, Rs.31945, Rs. 46945.78, Rs.35086.38, and Rs.50310.84 per hectare. The three type of marketing channel identified in the study area were Channel-I: Producer - Consumer, Channel-II: Producer - Retailer consumer and Channel-III: Producer - Wholesaler - Retailer - Consumer. Price spread of mustard cultivation in channel-I net price received by the producer in consumer's rupee 95.82 per cent was found and total marketing cost is 4.18 per cent. Chanel-II net price received by the producer in consumer rupee's 90.59 per cent and total marketing cost was found is 9.41 per cent. Channel-III net price received by the producer in consumer rupee's 83.53 per cent and total marketing cost is 16.47 per cent. More than 81.00 per cent rapeseed-mustard producers perceived that transportation of small quantity of produce was not an economical option if they sold their small produce in the market. The study suggested that urgent attention must be paid towards enhancing the productivity and marketing of rapeseed-mustard by providing improved and high yielding varieties, technology, irrigation, marketing, price support, policy and effective extension.

\section{Introduction}

Rapeseed-mustard belongs to family cruciferae and genus Brassica. Rapeseed (Brassica compestris) commonly called is Sarson or Toria is herbaceous annual plant shorter than mustard (rai) between $45-150 \mathrm{~cm}$. Mustard (Brassica juncea) common name is called rai. Rapeseed-mustard, its oil and its oil meal may contain anti-nutritiional factor such as goiterogens (thioglucosided or glucosinolates), tannic acid, erucic acid, sinapine (cholinester), pectins and oligosaccharides. Mustard stimulates digestion and salivary secretion. Mustard seeds have high energy content, having 28- 
$32 \%$ oil with relatively high protein content (28-36\%). The amino acid composition of mustard protein is well balanced; it is rich in essential amino acids. Mustard oil has $20-28 \%$ oleic acid, $10-20 \%$ linoleic and $30-40 \%$ erucic acid. India accounts for about 14.46 per cent of world's oilseeds area and 6.97 per cent of world's oilseeds output (FAO Year Book, 2013). It has second and third rank in the world in the production of groundnut $(8.2 \%)$ and rapeseed-mustard $(13.7 \%)$. The vegetable oil consumption in India is continuously rising and has sharply increased in the couple of years touching around $13.8 \mathrm{~kg} / \mathrm{head} /$ year. States ranking of oilseeds in 2012-2013 are Madhya Pradesh (29.93\%), Rajasthan (19.99\%) and Maharashtra (16.19\%) (Pocket Book on Agricultural Statistics, 2013). Total area, production and productivity in U.P. were 0.61 million hectare, 0.68 million tones and $1113 \mathrm{Kg} / \mathrm{ha}$ respectively (2009-10 Directorate of Economics and statistics, New Delhi). During the same period area, production and productivity of Mustard in Meerut District was 0.004438 million hectare, 0.0574351 million tones and $1324 \mathrm{~kg} / \mathrm{ha}$ respectively (2009-10). Very few studies have been conducted in the past to examine the production and marketing of rapeseed- mustard in Uttar Pradesh more so, in Meerut district and so looking to above facts, a study is essential to undertake through which a detailed insight can be obtained to analyse an economic analysis of production and marketing of rapeseed-mustard in Meerut district of Western Uttar.

\section{Materials and Methods}

Keeping in view the objective of the study, Meerut district of western Uttar Pradesh was purposively selected. Block wise data on the area under mustard and the total cropped area were obtaining from secondary sources. Based on data block wise percentage area under mustard to the corresponding total crop area of the block was calculating and these blocks were arranged in descending order. The two blocks with maximum percentage area under mustard were selected. For each selected block, percentage area under mustard to the corresponding total cropped area was worked out for each of the villages of the block and the ten villages having maximum concentration of relative area under mustard were selected from each of the selected two block. For each selected randomly of villages, a separate list of mustard growing farmers was prepared and these farmers was regarded in to marginal (below 1ha.), small (1-2 ha), medium (2-4 ha) and large (4 ha and above) size group of farms. From each selected randomly of villages, 100 farmers were randomly selected. The allocation of these 100 selected farms of a selected randomly of villages in to marginal, small, medium, and large farms was based on the proportion of the mustard growing farms under each size groups to the total mustard growing farms. Simple tabular analysis was applied to work out the cost of cultivation. The primary data were collected by survey method through personal interview on well-structured and pre tested schedule, while secondary data were collected from books, journals, report and records of the district and block headquarters. Both the tabular and functional analysis was used. Price spread was studied at the point of time in the selected markets. The prices for the purpose were calculated through the mode method. In mode method, model prices at different levels were obtained to work-out the gross margin of various agencies. To arrive at the net margins, the costs incurred by the concerned agencies were deducted from the gross margin.

\section{Results and Discussion}

The cost of cultivation of rapeseed-mustard production is presented in table 1 . It reveals that average total cost of cultivation was found to be Rs.50310.57/ha which was varies from Rs. 56834.60/ha at marginal farms to Rs. 46943.53/ha at large farms. 
Table.1 Costs of cultivation (Rs) of Mustard crop on different size group of sample farms in the study area

\begin{tabular}{|c|c|c|c|c|c|c|}
\hline \multirow[t]{2}{*}{ S. No. } & \multirow[t]{2}{*}{ Particular } & \multicolumn{4}{|c|}{ Size of sample farms (ha) } & \multirow[t]{2}{*}{ Overall averag } \\
\hline & & Marginal & Small & Medium & Large & \\
\hline 1. & Family labour & $\begin{array}{c}8210.51 \\
(14.44)\end{array}$ & $\begin{array}{c}2492.45 \\
(5.07)\end{array}$ & $\begin{array}{c}1803.71 \\
(3.82)\end{array}$ & $\begin{array}{c}1377.56 \\
(2.93)\end{array}$ & $\begin{array}{c}3140.06 \\
(6.24)\end{array}$ \\
\hline 2. & Hired labour & $\begin{array}{c}13115.78 \\
(23.07)\end{array}$ & $\begin{array}{c}11535.16 \\
(23.48)\end{array}$ & $\begin{array}{c}10297.50 \\
(21.82)\end{array}$ & $\begin{array}{c}10722.40 \\
(22.84)\end{array}$ & $\begin{array}{c}11280.13 \\
(22.42)\end{array}$ \\
\hline - & Total human labour & $\begin{array}{c}21326.29 \\
(37.52)\end{array}$ & $\begin{array}{c}14027.61 \\
(28.56)\end{array}$ & $\begin{array}{c}12101.21 \\
(25.64)\end{array}$ & $\begin{array}{c}12099.96 \\
(25.77)\end{array}$ & $\begin{array}{c}14420.19 \\
(28.66)\end{array}$ \\
\hline 3. & Tractor labour & $\begin{array}{c}4665.78 \\
(8.20) \\
\end{array}$ & $\begin{array}{c}4500.00 \\
(9.17) \\
\end{array}$ & $\begin{array}{c}4407.01 \\
(9.34) \\
\end{array}$ & $\begin{array}{c}4375.84 \\
(9.32) \\
\end{array}$ & $\begin{array}{c}4487.15 \\
(8.91) \\
\end{array}$ \\
\hline 4. & Bullock labour & - & - & - & - & - \\
\hline 5. & Seed & $\begin{array}{c}1209.36 \\
(2.13)\end{array}$ & $\begin{array}{c}1127.64 \\
(2.29)\end{array}$ & $\begin{array}{c}1154.95 \\
(2.44)\end{array}$ & $\begin{array}{c}1064.64 \\
(2.26)\end{array}$ & $\begin{array}{c}1107.57 \\
(2.20) \\
\end{array}$ \\
\hline 6. & $\begin{array}{l}\text { Manures and } \\
\text { fertilizers }\end{array}$ & $\begin{array}{l}7556.72 \\
(13.29)\end{array}$ & $\begin{array}{l}7143.96 \\
(14.54)\end{array}$ & $\begin{array}{c}6953.70 \\
(14.73)\end{array}$ & $\begin{array}{c}6474.45 \\
(13.79)\end{array}$ & $\begin{array}{c}7382.22 \\
(14.67)\end{array}$ \\
\hline 7. & Irrigation charge & $\begin{array}{c}3276.31 \\
(5.77)\end{array}$ & $\begin{array}{c}3105.52 \\
(6.32)\end{array}$ & $\begin{array}{c}3134.28 \\
(6.64)\end{array}$ & $\begin{array}{c}3113.79 \\
(6.63)\end{array}$ & $\begin{array}{c}3150.92 \\
(6.26)\end{array}$ \\
\hline 8. & Plant protection & $\begin{array}{c}1871.04 \\
(3.29)\end{array}$ & $\begin{array}{c}2052.74 \\
(4.17)\end{array}$ & $\begin{array}{c}2169.40 \\
(4.59)\end{array}$ & $\begin{array}{c}2715.51 \\
(5.78)\end{array}$ & $\begin{array}{c}2254.61 \\
(4.48)\end{array}$ \\
\hline 9. & Interest on working capital & $\begin{array}{c}644.10 \\
(1.14) \\
\end{array}$ & $\begin{array}{c}618.00 \\
(1.25) \\
\end{array}$ & $\begin{array}{c}670.61 \\
(1.42) \\
\end{array}$ & $\begin{array}{c}601.58 \\
(1.28) \\
\end{array}$ & $\begin{array}{c}632.03 \\
(1.25) \\
\end{array}$ \\
\hline 10. & Rental value of owned land & $\begin{array}{c}15000.00 \\
(26.39)\end{array}$ & $\begin{array}{c}15000.00 \\
(30.54) \\
\end{array}$ & $\begin{array}{c}15000.00 \\
(31.79) \\
\end{array}$ & $\begin{array}{c}15000.00 \\
(31.95)\end{array}$ & $\begin{array}{c}15000.00 \\
(29.81) \\
\end{array}$ \\
\hline 11. & Interest on fixed capital & $\begin{array}{c}1285.00 \\
(2.27)\end{array}$ & $\begin{array}{c}1534.08 \\
(3.12) \\
\end{array}$ & $\begin{array}{c}1368.28 \\
(2.89) \\
\end{array}$ & $\begin{array}{c}1273.26 \\
(2.71)\end{array}$ & $\begin{array}{c}1651.15 \\
(3.28) \\
\end{array}$ \\
\hline \multirow[t]{2}{*}{12.} & Land revenue & - & - & $\begin{array}{c}225.00 \\
(0.47) \\
\end{array}$ & $\begin{array}{c}225.00 \\
(0.47)\end{array}$ & $\begin{array}{c}225.00 \\
(0.44) \\
\end{array}$ \\
\hline & Grand total & $\begin{array}{c}56834.60 \\
(100.00)\end{array}$ & $\begin{array}{c}49109.51 \\
(100.00) \\
\end{array}$ & $\begin{array}{c}47184.44 \\
(100.00) \\
\end{array}$ & $\begin{array}{c}46943.53 \\
(100.00) \\
\end{array}$ & $\begin{array}{c}50310.84 \\
(100.00) \\
\end{array}$ \\
\hline
\end{tabular}


Table.2 Per hectare costs and income from the production of Mustard crop on various costs concept (Rs.)

\begin{tabular}{|c|c|c|c|c|c|c|}
\hline \multirow{2}{*}{ S. No. } & \multirow{2}{*}{ Particular } & \multicolumn{4}{|c|}{ Size of sample farms } & \multirow{2}{*}{ Overall average } \\
\hline & & Marginal & Small & Medium & Large & \\
\hline 1. & Cost $A_{1 /} A_{2}$ & 32339.09 & 30082.98 & 28787.45 & 29068.21 & 30294.63 \\
\hline 2. & Cost $\mathrm{B}_{1}$ & 33624.09 & 31617.06 & 30155.73 & 30341.47 & 31945.78 \\
\hline 3. & Cost $B_{2}$ & 48624.09 & 46617.06 & 45155.73 & 45341.47 & 46945.78 \\
\hline 4. & Cost $C_{1}$ & 41834.09 & 34109.51 & 31959.44 & 31719.03 & 35086.38 \\
\hline 5. & Cost $\mathrm{C}_{2}$ & 56834.60 & 49109.51 & 47184.44 & 46943.53 & 50310.84 \\
\hline 6. & Gross income & 67910.52 & 63500.00 & 58752.06 & 59634.48 & 61532.57 \\
\hline 7. & Net income & 11075.92 & 14390.49 & 11567.62 & 12691.48 & 11221.73 \\
\hline 8. & Family labour income & 19286.43 & 16882.94 & 13596.33 & 14293.01 & 14586.79 \\
\hline 9. & Farm investment income & 27360.92 & 30924.57 & 27935.90 & 28964.74 & 27872.88 \\
\hline 10. & Farm business income & 35571.43 & 33417.02 & 29964.61 & 30566.27 & 31237.94 \\
\hline 11. & Cost of production per $(q)$ & 2783.28 & 2461.75 & 2414.14 & 2583.57 & 2583.95 \\
\hline 12. & Yield (q/ha) & 20.84 & 19.94 & 19.54 & 18.17 & 19.46 \\
\hline 13. & Input output relationship & & & & & \\
\hline i) & On the basis of $\mathrm{C}_{2}$ & $1: 1.19$ & $1: 1.29$ & $1: 1.24$ & $1: 1.27$ & $1: 1.22$ \\
\hline ii) & On the basis of $\mathrm{C}_{1}$ & $1: 1.62$ & $1: 1.86$ & $1: 1.83$ & $1: 1.88$ & $1: 1.75$ \\
\hline iii) & On the basis of $B_{2}$ & $1: 1.45$ & $1: 1.36$ & $1: 1.30$ & $1: 1.31$ & $1: 1.31$ \\
\hline iv) & On the basis of $\mathrm{B}_{1}$ & $1: 2.01$ & $1: 2.00$ & $1: 1.94$ & $1: 1.96$ & $1: 1.92$ \\
\hline v) & On the basis of $A_{1} / A_{2}$ & $1: 2.09$ & $1: 2.11$ & $1: 2.04$ & $1: 2.05$ & $1: 2.03$ \\
\hline
\end{tabular}


Table.3 Inter comparison as a whole channel

\begin{tabular}{|c|c|c|c|c|c|c|c|}
\hline Sr. No. & Name of functionary & \multicolumn{2}{|c|}{ Channel-I } & \multicolumn{2}{|c|}{ Channel-II } & \multicolumn{2}{|c|}{ Channel-III } \\
\hline & & Rs./Q & $\begin{array}{c}\text { Producer \& } \\
\text { share in } \\
\text { consumer rupees }\end{array}$ & $\mathbf{R s . / Q}$ & $\begin{array}{c}\text { Producer \& } \\
\text { share in } \\
\text { consumer rupees }\end{array}$ & Rs./Q & $\begin{array}{l}\text { Producer \& share } \\
\text { in consumer rupees }\end{array}$ \\
\hline 1 & $\begin{array}{l}\text { Net price received by } \\
\text { producer }\end{array}$ & 3193.20 & 95.82 & 3171.93 & 90.59 & 3164.13 & 83.54 \\
\hline 2 & $\begin{array}{l}\text { Marketing cost incurred by } \\
\text { the producer }\end{array}$ & 139.11 & 4.18 & 103.45 & 2.95 & 133.25 & 3.51 \\
\hline 3 & $\begin{array}{l}\text { Producer sale } \\
\text { price/wholesaler purchase } \\
\text { price }\end{array}$ & - & - & - & - & 3297.38 & 87.04 \\
\hline 4 & $\begin{array}{l}\text { Marketing cost incurred by } \\
\text { the wholesaler }\end{array}$ & - & - & - & - & 164.77 & 4.35 \\
\hline 5 & Wholesaler net margin & - & - & - & - & 114.01 & 3.00 \\
\hline 6 & $\begin{array}{l}\text { Wholesaler sale price/ } \\
\text { retailer purchase price }\end{array}$ & - & - & 3275.44 & 93.54 & 3576.16 & 94.39 \\
\hline 7 & $\begin{array}{l}\text { Marketing cost incurred by } \\
\text { the retailer }\end{array}$ & - & - & 111.97 & 3.19 & 104.97 & 2.76 \\
\hline 8 & Retailer margin & - & - & 113.83 & 3.27 & 127.21 & 3.35 \\
\hline 9 & Total marketing cost & 139.11 & 4.18 & 329.25 & 9.41 & 623.58 & 16.46 \\
\hline 10 & $\begin{array}{l}\text { Retailer sale price/ consumer } \\
\text { price }\end{array}$ & 3332.31 & 100 & 3501.24 & 100 & 3787.71 & 100 \\
\hline
\end{tabular}


The higher cost incurred on cultivation was by marginal farms followed by large farms. The contribution of total labour cost for cultivation of crop was found to be Rs.18907.34/ha. The average total human labour share to total cost for cultivation was observed as Rs. 14420.19/ha which was 28.66 per cent to the total cost of cultivation, which was higher at marginal farms Rs.21326.29/ha. Followed by small Rs. 14027.61/ha., medium farms Rs. 12101.21/ha and large farms Rs. 12099.96/ha. When we see through the operation wise labour use, then the average intercultural operation cost was higher, followed by harvesting operation. The contribution of manures and fertilizers estimated was Rs. 7556.72/ha. (13.29 per cent) marginal farmers followed by Rs. 7143.96/ ha. (14.54 per cent) small farms, Rs. 6953.70/ha. (14.73 per cent) and Rs. 6474.45/ha. (13.79 per cent) at large farms. The figure shows that total input cost decreased with farm size. Yield, cost and return of rapeseed-mustard at the sampled farms. The yield, value of output per hectare and cost of production per quintal of rapeseed-mustard on the sample farms have been worked out in table 2 . It indicates that the average yield per hectare of rapeseedmustard came to 19.46 qtl./ha. Where higher yield was found at marginal farms (20.84 qtl./ha.) and the lowest was observed at large farms (18.17 qtl./ha.). The average gross return estimated was Rs. 61532.57/ha. Which was varies from Rs. 67910.52/ha. At marginal farms and Rs. 59634.48/ha. At large farms. The average net return was calculated as Rs. 11221.73/ha. Which was higher at small farms (Rs.14390.49/ha.), followed by marginal farms (Rs. 11075.92/ha.), which is found economically best for farmers.

\section{Inter comparison channel of marketing}

Quantity sold of rapeseed-mustard the three type of marketing channel identified in the study area were as Channel-I: Producer consumer, Channel-II: Producer - Retailer consumer and Channel-III: Producer Wholesaler -Retailer - Consumer at the producer level. The quantity sold by the producers is given in table 3 It is clear that three types of Inter channel comparison of price spread, marketing cost and margin of retailer and wholesaler Sardhana market of Meerut is displayed in table 3. Inter channel comparison reveals that the gross price and net price received by the producer was maximum in channel-I (Producer- Consumer) followed by channel-II (Producer- RetailerConsumer) and channel III (ProducerWholesaler- Retailer- Consumer).

\section{Acknowledgement}

The authors are thankful to the HOD, Department of Agricultural economics, NDUA\&T, Kumarganj, Faizabad (U.P.) for providing facilities for conducting research.

\section{References}

Bhatia, M.S., 1994. Agricultural pricing, marketing and international trade under new economic environment, Indian Journal Agricultural Economics, 49 (3):402-416.

Carre, P., Pouzet, A. 2014. Rapeseed market, worldwide and in Europe. Oilseeds and Fats, Crops and Lipids; 21(1):D102. 18.

Das, K.K., and Amod Sharma 2012. Growth and variability in area, production and yield of rapeseed and mustard crop in Nagaon district of Assam. Progressive Agriculture, 12(2): 392-395.

Gangwar Arpita, and Singh, Virendra 2015. An analysis of supply response of rapeseed-mustard in different regions of Uttar Pradesh. Journal of Oilseed Brassica, 6(1): 158-166.

Gautam, D.S., 1993. Profit structure of bajra, 
wheat and rapeseed/ mustard cultivation in central India. Indian journal of Agricultural Research: 1999.33:3,171177.

Mohinder Singh Luhach, V.P. Khatkr, R.K. Hasijia, R.C. 2009. Cost, returns and marketing of rapeseed and mustard in Haryana. Environment and Ecology: 2009. 27:1, 154-156.

Raju, K.S.R., Nagabhushanan, T.D.T 1986. "Supply response of major oilseed crops in different region of Andhra Pradesh" Agricultural Situation in India, 41(9), pp 747-750.

Ruza, L., 2009. Assessment of rapeseed production in the regions of Latvia and farms of different size. (Economic Science for Rural Development, No.20) Finances, taxes, investment and support systems. Proceedings of the International Scientific Conference, 23-24 April, 167173.

Sachan, R.C., Lijo Thomas Sharma, A. K. Jha, S. K. 2009. Economic utility evaluation of improved technologies in Indian mustard: an analysis of front line demonstrations. Indian Research Journal of Extension Education; 9(2):64-67. 4

\section{How to cite this article:}

Prince Kumar, K.K. Singh, Rajeev Singh, Swatantra Pratap Singh and Yamuna Prasad Singh. 2017. An Economic Analysis of Production and Marketing in Rapeseed-Mustard Crop in Meerut District of Western Uttar Pradesh India. Int.J.Curr.Microbiol.App.Sci. 6(9): 703-709. doi: https://doi.org/10.20546/ijcmas.2017.609.086 